\title{
A Sociolinguistic Experiment in Defining the Forms of Impoliteness
}

\section{Соціолінгвістичний експеримент у визначенні форм і засобів неввічливості}

\author{
Svitlana Formanova \\ Doctor in Philology, \\ Professor
}

\author{
Світлана Форманова \\ доктор філологічних наук, \\ професор
}

E-mail: svetlanaformanova@gmail.com orcid.org/0000-0001-9434-1903

\section{Tetiana Dombrovan \\ Doctor in Philology, Professor}

\author{
Тетяна Домброван \\ доктор філологічних наук, \\ професор
}

E-mail: dombrovan@gcn.ua orcid.org/0000-0003-3119-5499

Odessa I.I. Mechnikov University

2, Dvoryanskaya Str., Odessa, Ukraine, 65082
Одеський національний університет імені I.I. Мечникова $\triangle$ вул. Дворянська, 2, Одеса, Україна, 65082

Original manuscript received July 06, 2018

Revised manuscript accepted February 25, 2019

\begin{abstract}
The importance of the study is determined by the need for a comprehensive analysis of the conducted sociolinguistic experiment in order to identify the forms and means of impoliteness and to clarify the linguistic status of the latter. The objective of the article is, by means of a survey, to find out the forms, types and means of impoliteness among the student youth. The investigation of social awareness of the anti-etiquette space based on the analysis of the SE participants' answers has never before been
\end{abstract}


in the focus of linguists. The object of the study is the sociolinguistic experiment, the subject being the characteristics of forms and means of impoliteness. The following scientific methods are employed: the method of observation - to fix linguistic and non-linguistic expressions of anti-etiquette forms; the descriptive method - to identify the characteristic features of forms and means of impoliteness; analysis and synthesis of factual material in order to systematize and classify the factual material; the field research method with a questionnaire as its most common technique - to collect the corpus; the quantitative method and the method of sociolinguistic analysis of the collected corpus - to process the revealed facts about the subject of the study; the psycholinguistic method - to process and analyze the speech data received from informants as a result of questioning, which helped to establish the forms, types and methods of impoliteness among students. Findings. The authors claim that a high degree of impoliteness in the speech of young people is a means of self-expression and self-establishment, a striving for violation of social taboo, a way to set up one's own communicative rules. The use of the anti-etiquette forms of communication is influenced by a variety of factors such as age, sex, social status, area of residence, education, and profession. The survey has revealed certain differences in the regional use of the anti-etiquette forms in Ukraine. Being accurate and emotionally colored, those forms express a negative phenomenon which sometimes exists in the process of communication.

Key words: sociolinguistic experiment, survey, questioning, impoliteness, anti-etiquette, invective, non-codified lexis.

\section{Introduction}

As early as in the 1930s the famous Russian philologist Lev Scherba pointed at the significance of the linguistic experiment (LE). In his article, the title of which can be translated as «On the triple aspect of linguistic phenomena and the experiment in language study» (1931), L. Scherba emphasized the necessity of the experiment in linguistics. He wrote the following: «A researcher of living languages must ground his study on the understandable material. However, having built a certain abstract system from the facts of that material, one should verify it according to new facts, that is, to see if the facts coming from it correspond to reality. Thus, the principle of experimentation is introduced into linguistics. Having made some assumption about the meaning of this or that word, one form or another, about one or another rule of word formation, etc., one may try to say one or another phrase (which can be infinitely multiplied by using this rule)» (Scherba, 1965: 368). 
Then, L. Scherba (1965) states that the experiment can have not only a positive, but also a negative result. In this case, we can talk about the incorrectly postulated rule or the need for some corrections of the latter, or even that the rule does not work any longer, leaving traces in the form of the dictionary facts (ibidem). L. Scherba (1965) insisted on the significance of the experiment because it allows much deeper penetration into the understanding of man's speech activity. The theory of L. Scherba (1965) was further developed by M. Panov (Russia) and V. Labov (the USA), who in the early 1960s, independently of each other, paid attention to the experiment as a necessary stage to confirm the evidence of theoretical positions in sociolinguistic studies. Since then, experimental sociolinguistics has been developing and improving (Belyanin, 2003; Chemla, 2009; Dombrovan, 2018; Formanova, 2012, 2013a, 2013b; Martinek, 2007; Noveck \& Reboul, 2008; Schwarz, 2017).

The objective of the article is, by means of a survey, to find out the forms, types and means of impoliteness and rudeness among the student youth. The study of social awareness of the anti-etiquette space on the basis of the participants' replies in the experiment has not yet been the subject of an independent analysis. Therefore, the tasks of the present research include: 1) the definition of the theoretical basis for conducting surveys; 2) a description of the results of the survey, which highlighted changes in the mindset of respondents in the field of impoliteness.

\section{Sources, Evidence and Methods}

Experimental studies in linguistics allow analyzing the language facts through tracking their perception by native speakers, who act as informants during the survey. The need for a sociolinguistic experiment enables highlighting the specific features of the relationship between the speaker and the society, to establish the peculiarities of the social coding of the language and to characterize the linguistic background of the modern ordinary citizen.

The history of experimental studies in modern linguistics falls into three periods: 1) the intensive use of experimental methods in phonetics; 2) awareness of experimental methods as the most important way of obtaining data on communication in general, including its 
morphology, syntax, semantics, as well as problems of linguistic norm, linguistic contacts, pathology of linguistic development, etc.; 3) realization of the mentioned scientific program with the deepening of methodological reflections on the specifics of experimental studies in linguistics in comparison with experimental researches in other sciences (Yartseva, 1990: 590-591). Nowadays, experimental studies come beyond linguistics proper and tend to acquire an interdisciplinary trait.

In recent sociolinguistic experiments, linguists widely employ the psycholinguistic method, which involves the processing and analyzing linguistic facts obtained from informants as a result of their filling in special questionnaires. The core of the psycholinguistic methodology is the understanding of language as a system available in the mind of a person, which makes it possible to turn to the speaker as an expert capable of evaluating linguistic facts. In our experimental study, we analyzed the speech reactions and evaluations of the linguistic phenomena of impolite forms of communication by informants in modern Ukrainian society and their general attitude to this phenomenon.

In this paper, we used a sociolinguistic experiment (SE) to detect impolite communication and the use of anti-etiquette forms, including the invective space, and to investigate specific findings of the continuum of impoliteness among the respondents. We analyzed motives that provoked the use of rude, anti-etiquette and invective forms and the reasons and conditions for their manifestation in communication.

Other methods of the investigation include: the general method of observation (to note lingual and non-lingual expressions of antietiquette forms), the method of description (to identify and reveal the characteristic features of forms and means of impoliteness), the methods of analysis and synthesis of the corpus (in order to systematize and linguistically qualify the facts), the method of field research with its most common questionnaire for the collection of research material, the quantitative method and the method of sociolinguistic analysis of the collected corpus (to work with the findings of the subject of the study), the psycholinguistic method (for processing and analyzing linguistic data obtained from native speakers' questionnaires; also for the analysis of assessments of linguistic phenomena by respondents, which enabled establishing forms, types and methods of impoliteness among students).

Our research lays the foundation stone for socio-psycho-linguistic studies as a new vector in the field of linguistics. Both sociolinguistic 
and psycholinguistic studies each highlight certain aspects of a lingual personality. However, the latter exists objectively as a complex (synergetic) phenomenon whose being and functioning is determined by the non-linear interaction of various types of socio-psycholinguistic factors. Hence, there is a growing need for considering language in its anthropocentric socio-psycho-linguistic dimension (Dombrovan, 2018; Filon \& Halunova, 2015; Formanova, 2012). Sociolinguistics and psycholinguistics focus on related problems and have very much in common, including the identical object and methods of research, etc. There are scientific investigations of psycholinguistic problems of ontogenesis and those of sociolinguistics, which are in line with a psycholinguistic component. All this justifies the socio-psycho-linguistic aspect within the framework of our sociolinguistic experiment.

In this paper, we agree with M. Filon and N. Halunova (2015) about a certain limitedness of one-disciplinary research methodology (see also: Dombrovan, 2018: 20-32). That explains why we undertake a complex, interdisciplinary approach to the lingual personality studies, revealing the age component, the gender component, and the social as well as cultural components in the formation of respondents' speech conduct while using personal invectives.

\section{Results and Discussion}

In what follows, we draw attention to the facts established through a socio-psycho-linguistic survey of students of higher educational establishments of Vinnytsia, Lviv and Odessa (Ukraine). The experiment lasted for five months from December 2016 to April 2017 and was implemented in the form of an anonymous written survey, in which, besides the questionnaire, respondents were required to indicate the place of their permanent residence, their age and gender, in order «to achieve maximum purity of the experiment» (Formanova, 2013a: 69).

Another point was important for our research, namely the following: psycholinguistics differentiate between the objective and the subjective semantics of a word. The former is the semantic system of meanings; the latter represents the system of associations emerging in a person's mind (Belyanin, 2003: 129). Recent research on speech generation and perception show that the problem of the influential 
power of the word is far from being solved. According to V. Belyanin, 'it is still not known how the words affect people and how the power of any nature uses their power' (Belyanin, 2003: 209). He notes that the statement may not only contain useful information for the addressee, but also terms of abuse, i.e. insulting words, embodied in the communicative act (Belyanin, 2003: 210).

Returning to our research, we should mention that 60 respondents, aged 17-24 years old, from Lviv, Vinnytsia and Odessa participated in the sociolinguistic experiment, among them 39 females (65\%), 21 males $(35 \%)$, i.e. 20 people from each region. The focus on the specified age amplitude is due to the fact that this period is marked by the formation of the conceptual system of a personality's coordinates, the activity of the person's behavioral strategies and tactics.

The respondents were to complete a questionnaire, which is considered to be the most common method of collecting factual data both in sociolinguistics and in psycholinguistics. The questionnaire included three parts: introductory, sociological and linguistic proper. The introductory part outlined the purpose of the survey; the sociological part of the questionnaire contained questions related to the sociodemographic and biographical nature of the informant (his / her sex, age, nation, mother tongue, professional status, cultural and educational level, etc.). The linguistic proper part concerned the use of anti-etiquette forms by the respondents.

The respondents were asked to answer twenty questions which aimed to establish the scope and limits of the use of impolite forms in communication as well as the respondents' attitude to this phenomenon. The questions also allowed tracing gender distinctions in the use of antietiquette forms of communication, thus revealing the level of activity of the so-called negative linguistic space. It should be mentioned here that the problem under consideration represents a kind of anomaly, for anti-etiquette utterances come into conflict with linguistic intuition, knowledge of language norms and the culture of communication.

The application of the quantitative and qualitative method of analysis of the obtained data has revealed that the choice of speech behaviour patterns is influenced by the speaker's gender and social status. Such external factors as the degree of formality of the situation (i.e. informal, semi-formal, formal), the grade of aggressiveness of communicants in conflict / conflict-free situations are of paramount 
importance. Noteworthy is the fact that males tend to use less expressive language means towards females; women, by contrast, widely employ offensive expressions if their personal qualities or character traits are affected.

Linguistic studies of impoliteness in the Ukrainian-language discourse aim: 1) to identify the potential values that are foregrounded in the communication process; 2) to determine the status of antietiquette forms of communication in the Ukrainian language; and 3) to explain the perception and evaluation of certain non-codified statements by Ukrainian speakers.

Impoliteness as a psycho-sociolinguistic phenomenon is one of the most researched topics in modern linguistics. This is due to the fact that scholars seek to learn a language from the cognitive-communicative point of view. Despite the growing interest in this phenomenon, linguists and lexicographers still do not have a common opinion regarding the term «impoliteness». Today, the terminology apparatus and the content of the basic concepts for description of impolite and rude communication, remain poorly developed both in pragmatics and linguistics.

The linguistic behavior of a modern Ukrainian suffers from the so-called «anti-etiquette» including vulgarisms, swear-words, curses, etc., which offend, humiliate, and wish evil. Anti-etiquette also has a large number of non-verbal signs that accompany speech and/or work independently. They are not the same in terms of invectiveness, offense for the addressee or a third person, but they all have a rough and obscene expressiveness that makes them unacceptable from the point of view of etiquette and culture of communication. Recently, the dominant form of achieving the communicative goal is linguistic aggression, which manifests itself in the excessive use of the invective, jargon, obscene, negative emotional vocabulary, which degrades and offends the communicative partner, complicates interaction and often leads to a serious conflict situation through a demonstration of the position against the opponent and reflects domination over the latter.

Anti-etiquette forms of communication as a socio-cultural phenomenon appeared as a result of the need of society in their presence, in particular due to the desire of man to receive destructive knowledge about the world, traditions, and etiquette. Anti-etiquette forms of communication have entered the sphere of mutual relations, as well as other kinds of human activity and of society's existence. However, 
they rely on cultural traditions, values, and norms developed in a given society. In the Ukrainian language, the most commonly used invectives are associated with the natural functions of the body reflected in the so-called corporal-rectal vocabulary (i.e. connected with the process and products of defecation). With the help of such words and expressions people can demonstrate their emotional state. The state can either be caused by something definite in the environment or have nothing to do with it. Often, anti-etiquette behaviour is typical for the young people since it is precisely the youth who seek self-expression and freedom (Formanova, 2013b: 235).

The results of the sociolinguistic experiment indicated that in different cities of this country the anti-etiquette forms of communication have their own peculiarities. Moreover, the spread of anti-etiquette forms differs from region to region and is closely interconnected with the history and culture of the area. The survey provided some useful insight into the gender aspect of the problem: the obtained data has revealed that the anti-etiquette forms are much more common in the speech of males rather than in the speech of females. On the whole, the survey has exposed a high level of impoliteness in modern Ukrainian society and a tendency to legitimate obscenities.

The empirical data was classified according to the communicative situations in which the anti-etiquette forms had been used. The quantitative method helped us to analyze and interpret the data. Here are the most vivid examples.

In the respondents' opinion, the anti-etiquette forms include:

- violation of etiquette norms - 22 situations (36.6\%);

- violation of moral norms - 15 cases $(25 \%)$;

- impoliteness - 12 (20\%);

- violation of norms of communication - 8 (13.3\%);

- use of slang - $3(5 \%)$.

The first time the respondents heard the anti-etiquette forms was:

- early childhood - 36 people $(60 \%)$;

- school years -24 people $(40 \%)$.

The anti-etiquette forms were first heard from:

- friends - 25 people $(41.6 \%)$;

- adults - $23(38.3 \%)$;

- relatives - $4(6.4 \%)$;

- hard to remember $-8(13.3 \%)$. 
The anti-etiquette forms are used:

- to express one's negative emotions - 27 (45\%);

- to communicate - $17(28.3 \%)$;

- to feel more confident - $6(10 \%)$;

- for no definite purpose - $10(16.6 \%)$.

While using the anti-etiquette forms, the respondents feel:

- annoyed - 21 (35\%);

- uncomfortable - $18(30 \%)$;

- neutral - 17 (28.3\%);

- confident - 4 (6.6\%).

The respondents use the anti-etiquette forms:

- very often - $26(43.3 \%)$;

- from time to time - $21(35 \%)$;

- $\quad$ seldom - 13 (21.6\%).

The anti-etiquette forms are commonly used:

- $\quad$ among friends - 28 (46.6\%);

- in various life spheres - $21(35 \%)$;

- in communication with one's relatives - 11 (18.3\%).

The respondents admitted using the anti-etiquette forms:

- in communication with friends - $41(68.3 \%)$;

- in communication with neighbours - 38 (63.3\%).

At the same time, the respondents claimed that they avoid the anti-etiquette forms in more formal situations, including:

- communication with people higher in rank or post - 56 (93.3\%);

- communication with one's parents - 39 (65\%).

In the opinion of the respondents, the anti-etiquette forms are used in their environment:

- very often - $30(50 \%)$;

- very seldom - 19 (31.6\%);

- from time to time - $11(18.3 \%)$.

When asked about their attitude to the anti-etiquette forms, the respondents chose the following alternatives:

- negative - $38(63.3 \%)$;

- neutral - 17 (28.3\%);

- positive - $5(8.3 \%)$.

The majority of the respondents (52 people, or $86.6 \%$ ) feel aversion to those who use the anti-etiquette forms. 37 respondents (or 61.6\%) 
reported that the anti-etiquette forms evoke negative emotions, while 23 respondents $(38.3 \%)$ have a neutral attitude to the anti-etiquette forms.

One of the questions was, What is your attitude toward the use of the anti-etiquette forms in your own family? 47 respondents $(78.3 \%)$ expressed their irreconcilability, and 11 people (21.6\%) consider their use tolerable.

Another question was, Do you think that there exist certain situations in which the use of the anti-etiquette forms is appropriate? To it affirmatively answered 34 respondents $(56.6 \%)$, the rest (26, or $43.4 \%$ ) gave a negative answer.

The respondents also mentioned the anti-etiquette forms which they usually used, namely:

- insults - $23(38.3 \%)$;

- abuse - $18(30 \%)$;

- $\quad$ swear-words - $13(21.6 \%)$;

- curses $-6(5 \%)$.

To the question, Do you think one should avoid any impolite words? only 28 participants answered 'Yes' (46.6\%), while 32 people $(53.4 \%)$ chose 'No'.

The results of the survey show that anti-etiquette forms of communication have their regional peculiarities. For example, residents of Lviv region are characterized by the use of curses in their speech, while respondents from Vinnytsia and Odesa regions did not specify this form. In general, Lviv residents do not take anti-etiquette positively and try to avoid any possible forms of impoliteness.

Curses appear from hatred and anger and are a visiting card for western Ukrainians, who consider them to belong to the most sophisticated and worst vocabulary, performing a rather suggestive function, thus producing a sort of magic effect on the addressee. This is a verbal simulation of a conflict / unpleasant situation, in which the two people involved in the communication find themselves (Formanova, 2012: 158-159). As defined in the 'Lexicon of General and Comparative Literary Studies' (2001: 449), curses are «a small folk genre conveying the wishes of misery, unhappiness, punishment, and even the death of man, animals, or plants». The national-cultural phenomenon forms the individual's perception of the world, from which the linguistic picture of the human world is drawn up, verbalizing the existing experience of the individual and / or society. 
Among the inhabitants of Vinnytsya, anti-etiquette is expressed, first of all, in abuse and insults, and sometimes in swearing. But the Vinnytsia people, in spite of the prevalence of impolite forms of their communication, generally expressed a strong negative attitude to them.

Odessa seems the most tolerant towards anti-etiquette. The survey has revealed that the respondents from the southern region of Ukraine commonly use the means of impoliteness in all spheres of their life. Thus, Odessa respondents allow themselves to use the anti-etiquette forms in their communication with their parents, and sometimes even with people of a higher rank. The choice of impolite forms of communication is influenced not so much by a social position, as by the individuality of the communicative partner, his / her personal attitude to the invective and anti-etiquette forms of communication. Moreover, a certain awareness and controllability are still observed in the speech of respondents from Odessa. The data obtained during the sociolinguistic experiment is clear evidence of a gradual legitimization of the invective.

Regarding the gender aspect (see Fig. 1), invectives are more used by men $(90.4 \%)$ than women $(56.4 \%)$. Among males, the use of swear words is dominant, while young girls prefer offensive words.
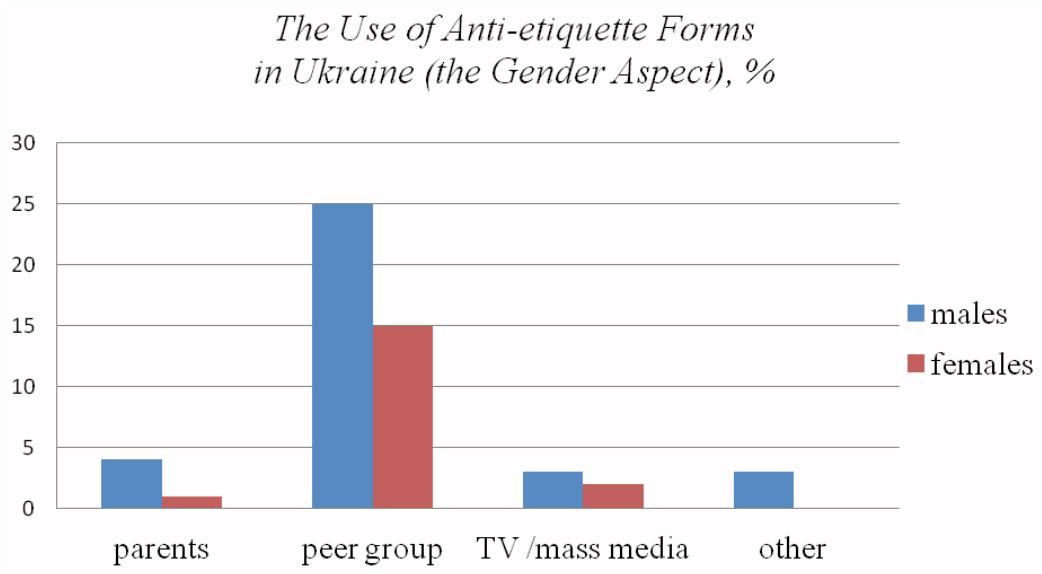

Fig. 1. The gender aspect of the use of anti-etiquette forms in Ukraine

The results of the survey showed that the speech of men is characterized by the use of the invective, jargon, emotionally marked vocabulary, the use of obscene words as linking words or phrases in a sentence (to some extent, they are used as insertions) when referring to 
relatives, friends, women. The use of an invective referring to actions and processes often reflects the speaker's highly emotional state.

Women tend to use neutral words, euphemisms, evaluative statements, exclamations, amplifying particles, etc. Thus, the speech of women does not imply the rigidity of the meaning which is inherent in the language of men.

\section{Conclusion}

The results of the socio-psycho-linguistic experiment lead to the following conclusions:

1. The anti-etiquette forms are widely spread in the communication of Ukrainian youth. The survey completely confirms the thesis about a high level of impoliteness in modern society.

2. The use of the anti-etiquette forms of communication is influenced by a variety of factors such as age, sex, social status, area of residence, education, profession, etc.

3. The anti-etiquette forms differ in a gender aspect. Namely, in their speech, 90.4\% males commonly use swear-words, while $56.4 \%$ females prefer insult words.

4. The social role of a respondent influences his/her choice of invectives.

5. The obtained data enabled a creation of the so-called 'sociolinguistic portrait of a speaker' to characterize the speaker's typical features, habits, peculiarities of his/her personality social space, etc.

6. There exist certain differences in the regional use of the antietiquette forms in Ukraine. There is a tendency to avoid impolite words in Lviv; in Vinnytsia, they are often used but are disliked; while Odessa is relatively tolerant to any rude forms of communication.

7. The survey not only revealed the scope of impoliteness, but also helped to understand the real motives for its use. A high degree of impoliteness in the speech of young people is a means of self-expression and self-establishment, a striving for violation of social taboos, a way to set up one's own communicative rules.

Our future research is seen in conducting a socio-psycholinguistic survey among representatives of middle and older age in order to obtain fairly representative and objective data on the anti-etiquette 
forms in particular and the invective space in general. This will allow us to characterize various social groups that create the linguistic community in this country and to determine the degree of impoliteness among the age groups of the population.

\section{References}

Belyanin, V.P. (2003). Psyholingvistika [Psycholinguistics]. Moscow: Moscow Psychological and Social Institute [in Russian].

Chemla, E. (2009). Presuppositions of quantified sentences: experimental data. Natural Language Semantics, 17(4), 299-340. https://doi.org/10.1007/s11050-009-9043-9

Dombrovan, T. (2018). An Introduction to Linguistic Synergetics. UK: Cambridge Scholars Publishing.

Filon, M.I., \& Halunova, N.M. (2015). Na shliakhu piznannia antropotsentrychnoho buttia movy: ukrainska sotsiopsykholinhvistyka kintsia XX - pochatku XXI stolittia [On the Way of Cognition of Anthropocentric Being of the Language: Ukrainian Socio-Psycholinguistics of the end of the XXth - the beginning of the XXI century]. Visnyk Xarkivskogo nacionalnogo universytetu imeni V.N. Karazina - Bulletin of the Kharkiv National University named after V.N. Karazin, 73, 22-25 [in Ukrainian].

Formanova, S.V. (2013a). Antyetyketni formy spilkuvannia [Anti-etiquette forms of communication]. Mova - Language, 19, 65-69 [in Ukrainian].

Formanova, S.V. (2013b). Sotsiolinhvistychnyi eksperyment yak sposib vyznachennia invektyvnosti [Sociolinguistic experiment as a means of defining invectives]. Naukoviy visnyk PNPU im. K.D. Ushinskogo - Scientific Herald of the K.D. Ushinsky National Pedagogical University, 16, 234-240 [in Ukrainian].

Formanova, S.V. (2012). Invektyva v ukrayinskyi movi [Invective in the Ukrainian language]. Kyiv [in Ukrainian].

Yartseva, V.N. (Eds.). (1990). Lingvisticheskiy entsiklopedicheskiy slovar [Linguistic Encyclopedic Dictionary]. Moscow: Sovetskaya entsiklopediya [in Russian].

Leksykon zahalnoho ta porivnialnoho literaturoznavstva [Lexicon of general and comparative literary criticism]. (2001). Chernivtsi: Zoloti lytavry [in Ukrainian].

Martinek, S.V. (2007). Ukrainskyi asotsiatyvnyi slovnyk [The Ukrainian associative dictionary]. (Vols. 1-2). Lviv: Vidavnichiy tsentr LNU imeni Ivana Franka [in Ukrainian].

Noveck, I., \& Reboul, A. (2008). Experimental pragmatics: a gricean turn in the study of language. Trends in Cognitive Sciences, 12(11), 425-431. https://doi. org/10.1016/j.tics.2008.07.009

Scherba, L.V. (1965). O troyakom aspekte yazyikovyih yavleniy i ob eksperimente $\mathrm{v}$ yazyikoznanii [On the triple aspect of language phenomena and on the experiment in linguistics]. Istoriya yazyikoznaniya XIX-XX vekov $v$ ocherkah $i$ izvlecheniyah - A History of Language Studies in XIX-XX cc in essays and abstracts (pp. 361-373). Moscow: Prosveschenie [in Russian].

Schwarz, F. (2017). Experimental Pragmatics. doi: 10.1093/acrefore/ 9780199384655.013.209 


\section{АНОТАЦІЯ}

Актуальність дослідження визначається необхідністю комплексного аналізу проведеного сочіолінгвістичного експерименту з метою визначення форм i засобів неввічливості та з'ясування його лінгвістичного статусу. Метою статmі $\epsilon$ за допомогою опитування з'ясувати форми, види й способи неввічливості серед студентської молоді. Вивчення соціального усвідомлення антиетикетного простору на матеріалі відповідей учасників експерименту ще не було предметом самостійного аналізу. Об'єктом статmі $\epsilon$ сочіолінгвістичний експеримент. Предметом статті є характеристика форм і засобів неввічливості. Опрацювання мовного матеріалу зумовило застосування таких загальнонаукових методів: спостереження - для фіксації мовних та позамовних виражень антиетикетних форм, описовий - для ідентифрікації та виявлення характерних особливостей форм і засобів невічливості, аналізу та синтезу фактичного матеріалу, що уможливило систематизацію й об'єктивну лінгвістичну кваліфікацію фрактичного матеріалу, метод польового дослідження з його найпоширенішим прийомом - анкетуванням для збору матеріалу дослідження, метод кількісних підрахунків та метод соціолінгвістичного аналізу зібраного матеріалу - для обробки виявлених фрактів про предмет дослідження, психолінгвістичний метод - для обробки й аналізу мовних даних, одержаних від інформантів у результаті анкетування й для аналізу оцінок мовних явищ респондентами, що уможливило встановлення форм, видів і способів неввічливості серед студентства. Висновки. Антиетикетні форми спілкування є одним із засобів самовираження молоді та їі прагнення зруйнувати суспільні табу. Виявлено, що на використання антиетикетних форм спілкування впливають різноманітні чинники: вік, стать, соціальний статус, місце проживання, виховання, освіта, професія тощо. 3'ясовано, що на сьогодні існують відмінності у вживанні антиетикетних форм спілкування серед жителів різних регіонів України. Досліджувані форми є емоційно й експресивно забарвленими, оцінними й виражають негативне явище, що іноді дозволяє найповніше передати усі нюанси спілкування.

Ключові слова: соціолінгвістичний експеримент, опитування, анкетування, неввічливість, антиетикет, інвектива, некодифікована лексика.

\section{Форманова Светлана, Домброван Татьяна. Социолингвистический} эксперимент в определении форм и способов невењливости

\section{АННОТАЦИЯ}

Актуальность исследования определяется необходимостью комплексного анализа проведенного социолингвистического эксперимента с целью определения форм и средств невежливости и выяснения его лингвистического статуса. Целью статьи является выяснение форм, видов и способов невежливости среди студенческой молодежи с помощью опроса. Изучение социального осознания антиэтикетного пространства на материале ответов участников эксперимента еще не было предметом самостоятельного 
анализа. Объектом статьи является сочиолингвистический эксперимент. Предметом статьи является характеристика форм и средств невежливости. Обработка речевого материала обусловила применение таких общенаучных методов: наблюдение - для фиксации языковых и внеязыковых выражений антиэтикетных форм, описательный - для идентификации и выявления характерных особенностей форм и средств невежливости, анализа и синтеза фактического материала, что позволило систематизировать и объективно лингвистически классифицировать фактический материал, метод полевого исследования с его самым распространенным приемом -анкетированием - для сбора материала исследования, метод количественных подсчетов и метод социолингвистического анализа собранного материала - для обработки выявленных фактов о предмете исследования, психолингвистический метод - для обработки и анализа речевых данных, полученных от информантов в результате анкетирования и для анализа оценок языковых явлений респондентами, что способствовало установлению форм, видов и способов невежливости среди студенчества. Выводы. Антиэтикетные формы общения являются одним из средств самовыражения молодежи и ее стремление разрушить общественные табу. Выявлено, что на использование антиэтикетных фрорм общения влияют различные факторы: возраст, пол, социальный статус, место проживания, воспитание, образование, профрессия и т. д. Выяснено, что в настоящее время существуют различия в употреблении антиэтикетных форм общения среди жителей разных регионов Украины. Исследуемые формы являются эмоционально и экспрессивно окрашенными, оценочными и выражают негативную коннотацию, иногда некодифицированная лексика позволяет наиболее полно передать все нюансы общения.

Ключевые слова: социолингвистический эксперимент, опрос, анкетирование, невежливость, антиэтикет, инвектива, некодифицированная лексика. 